\title{
DIKOTOMI PENDIDIKAN ISLAM: Akar Historis dan Dikotomisasi Ilmu
}

\author{
Akhmad Asyari* \\ Rusni Bil Makruf**
}

\begin{abstract}
Abstrak: Pemisahan ilmu agama dan non-agama atau apa yang disebut dikotomisasi ilmu dalam wacana pendidikan Islam telah menimbulkan banyak perdebatan di kalangan tokoh pendidikan Islam. Sebagian tokoh medukung penuh sistem dikotomi dan sebagian menolak keras adanya dikotomi. Tulisan ini bertujuan untuk mengurai akar historis dikotomisasi pendidikan Islam. Hasil temuan ini menunjukkan bahwa Islam sangat menganjurkan eksplorasi ilmu pengetahuan dengan tidak memisahkan dan mempertentangkan antara ilmu agama dan ilmu non agama. Dalam Islam, tidak ada pendikotomian ilmu, yang ada hanyalah pengklasifikasian ilmu, akan tetapi pada praktiknya pengklasifikasian ilmu tersebut salah diartikan oleh banyak kalangan masyarakat muslim itu sendiri.
\end{abstract}

Kata kunci: Ilmu agama, ilmu umum, pendidikan Islam, dikotomi ilmu.

ejarah pasti berulang. Sebuah semboyan yang patut diperhatikan oleh umat manusia. Tentu saja ini berkaitan erat dengan sejarah peradaban manusia yang telah lama dibuat dan mengalami pasang surut kejadian. Terlepas dari unsur tersebut, maka kejadian-kejadian pada masa lalu kemudian akan menjadi pelajaran yang bermanfaat bagi kehidupan kita pada masa depan,

*Penulis adalah Dosen Tetap Jurusan PAI Fakultas Ilmu Tarbiyah dan Keguruan IAIN Mataram. Sekarang sedang menempuh Program Doktor Teknologi Pendidikan Kerjasama Universitas Negeri Jakarta dan Fakultas Ilmu Tarbiyah dan Keguruan IAIN Mataram. email: asyarismart@yahoo.com

${ }^{* *}$ Penulis adalah Alumni Jurusan PAI Fakultas Ilmu Tarbiyah dan Keguruan IAIN Mataram. 
El-HiKMAH, Volume 8, Nomor 2, Desember 2014

agar semua kejadian pada masa lalu menjadi acuan bagi setiap manusia agar bisa membangun peradaban yang lebih baik.

Pendidikan di era modern mengalami perkembangan yang sangat pesat, hal ini dikarenakan oleh arus globalisasi yang semakin lama semakin tidak terbendung, mau tidak mau, suka tidak suka, arus globalisasi itu tetap datang. Tidak mungkin lagi bertahan hanya dengan tradisi lama, akan tetapi menjadi sangat perlu untuk menyesuaikan diri dengan peradaban yang baru juga. Belakangan pendidikan mengalami pasang surut, ada kalanya pendidikan lebih mengarah pada cara manusia untuk mendapatkan materi sebanyak mungkin sehingga menjadikan pendidikan umum sangat popular dan sebaliknya yang terjadi pada pendidikan yang berbau "akhirat" menjadi termarjinalkan. Adakalanya berbanding terbalik, pendidikan agama menjadi sangat banyak diminati para pelajar dan pendidikan umum sedikit diabaikan. Maka jarang sekali keduanya bisa berimbang sehingga menambah lebar perseteruan pada wacana dikotomi pendidikan Islam dan hal inilah yang terjadi pada pendidikan Islam.

Imbas dari keduanya adalah berpetak-petaknya orientasi dari masing-masing orang dalam mendapatkan pendidikan, misalnya saja kaum agamawan "para pengabdi Tuhan" akan lebih cenderung memilih pendidikan agama dan menghinakan pendidikan yang hanya mementingkan materi semata_ajaran ini terlihat jelas pada tradisi para sufi Islam, pendeta Hindu dan kebanyakan tokoh-tokoh agamawan. Orang yang belajar agama di madrasah, masjid, gereja, vihara, pure dan tempat-tempat "suci" dianggap mendapatkan pahala besar dan belajar di gedung-gedung modern dianggap tidak mendapatkan pahala. Lebih parah lagi, para pendukung ilmu-ilmu agama hanya menganggap valid sumber ilahi dalam bentuk kitab suci dan tradisi kenabian dan menolak sumber-sumber nonskriptual sebagai sumber otoritatif untuk menjelaskan kebenaran sejati (Kertanegara, 2005: 22-23)

Kejadian sebaliknya dialami oleh para "pemuja" materi, walaupun tidak secara terang-terangan mengatakan tidak suka belajar agama akan tetapi dalam praktiknya mereka enggan 
mengikuti pembelajaran yang berorientasi pada ilmu agama. Datangnya filsafat sekuler menjadikan renggang yang makin jauh antara ilmu agama dan ilmu umum karena filsafat sekuler tidak hanya kontradiktif dengan fitrah manusia, bahkan juga dapat menyebabkan ilmu pengetahuan tercerabut dari akar-akar dan tujuan utama kelahirannya (Masruri dan Rossidy, 2007: 1). Akibat hal tersebut ilmuan-ilmuan sekuler hanya menganggap valid informasi yang diperoleh melalui pengamatan indrawi (Kertanegara, 2005:23). Jika, pada konsep ini, saling kelaim kebenaran terus terjadi maka bisa disimpulkan bahwa perdebatan panjang yang tak kunjung selesai akan terus terjadi dan hal ini justru akan memperparah keadaan keilmuan murni (keilmuan yang tidak berpihak pada salah satu jenis keilmuan), jenis ancaman lain yang akan terjadi adalah saling kafir-mengkafirkan dan saling tuduh sesat-menyesatkan dalam kelompok-kelompok Islam.

Pada tataran pendidikan Islam, Moh. Shofa menilai bahwa perkembangan pendidikan Islam kontemporer melahirkan dua arus pemikiran yang saling tolak belakang, keduanya mengambil bentuk yang berbeda, baik dari aspek materi, sistem pendidikan, maupun dari segi kelembagaan (Shofa, 2014: 6). Dua model yang dimaksud adalah pendidikan Islam yang bercorak tradisional (ke-Timur-an), yang dalam perkembangannya lebih menekankan aspek doktrinernormatif yang cendrung ekslusif-apologetis, hal ini terlihat dari kelompok Wahabi, Salafi, Hizbuttahrir (Islam kanan) dan kelompok lain yang memiliki tradisi yang hampir sama (cara berpakaian dan penampilan mengikuti tradisi Timur). Kelompokkelompok ini lebih banyak tidak berani mengkreasikan tafsiran alQur'an dan al-Hadits (mengutamakan pendekatan tekstual dan sedikit sekali menggunakan keilmuan lain). Model yang kedua adalah pendidikan Islam yang modernis (ala Barat) yang pada perkembangannya ditengarai mulai kehilangan ruh-ruh mendasarnya (transendentalnya). Pola pemikiran modernis ini banyak diterapkan oleh Islam sekuler, kalau dalam organisasi, kelompok JIL (Islam Kiri) bisa disebut sebagai salah satu penganut 
El-HiKMAH, Volume 8, Nomor 2, Desember 2014

pendidikan ala modern ini. Al-Hasil perang terbuka mengiringi wacana dikotomi ilmu pengetahuan Islam.

Hal ini menarik untuk dicermati, kenapa hal demikian bisa terjadi. Maka pisau analisis yang menurut pemakalah paling ampuh untuk mengkajinya adalah ilmu sejarah. Tulisan ini dihajatkan untuk mengurai akar historis dikotomisasi pendidikan Islam.

\section{Pengertian Dikotomi Pendidikan Islam}

Pemisahan pendidikan Islam dan non pendidikan Islam (baca, dikotomi pendidikan Islam) menjadi wacana menarik yang telah lama dibahas dalam pendidikan Islam. Wacana dikotomi ini menimbulkan banyak perdebatan dikalangan tokoh pendidikan, sebagian tokoh medukung penuh sistem dikotomi dan sebagian menolak keras adanya dikotomi. Untuk memberikan arti yang lebih komplit maka perlu kiranya adanya penjelasan istilah dalam memahami arti kata dikotomi pendidikan Islam. Penjelasan ini dianggap penting agar tidak mengaburkan terma pokok dalam mengkaji permasalahan dikotomi ilmu pengetahuan yang telah lama berkarat. Dalam berbagai kajian dalam pembahasan dikotomi pendidikan Islam, para ahli banyak menggunakan bahasa yang berbeda sehingga dalam membahas dikotomi maka perlu kiranya penyatuan istilah. Selain berbedanya istilah yang dipakai, ada juga terma-terma yang bukan hanya berbeda dalam pemakain istilah akan tetapi dalam hal lain yang jauh lebih subtansial.

Secara leksikal dalam Kamus Besar Bahasa Indonesia, dikotomi mempunyai pengertian sebagai pembagian atas dua kelompok yang saling bertentangan (Anonim, 2001: 264) Dua kelompok yang dimaksudkan tentu saja diperuntukkan bukan hanya pada dunia pendidikan akan tetapi mencakup semua hal yang bertentangan. Agak sedikit berbeda dijelaskan dalam kamus ilmiah popular sebagaimana yang diutarakan oleh Pius A. Partanto dan M. Dahlan al-Barry yang mengartikan dikotomi sebagai pembagian dalam dua bagian yang saling bertentangan (Partanto dan al-Barry, 1994:11). Sedangkan Mujammil Qomar mengartikan dikotomi sebagai pembagian atas dua konsep yang saling bertentangan (Qomar, 
2006: 74). Dalam pernyataan ini Muzammil Qomar membedakan pertentangannya pada tataran konsep saja. Jamaladdin Idris seperti yang dikutip oleh Yuldelasharmi mengartikan dikotomi sebagai pemisahan secara teliti dan jelas dari suatu jenis menjadi dua yang terpisah satu sama lain dimana yang satu sama sekali tidak dapat dimasukkan ke dalam yang satunya lagi dan sebaliknya (Yuldelasharmi, 2009:230). Dengan demikian, segala hal yang membagi sesuatu menjadi dua kelompok yang bebeda bahkan saling bertentangan antara kelompok tersebut adalah dikotomi. Berarti, pengertian dikotomi ilmu adalah membedakan, memisahkan ilmu menjadi dua kelompok atau dua bagian yang saling berbeda dan bertentangan.

Istilah dikotomi ilmu dalam berbagai literatur sejarah berbedabeda, untuk membedakan ilmu-ilmu agama dengan ilmu-ilmu umum banyak digunakan istilah-istilah diskursus yang berbeda pula, diantaranya digunakan kata "ilmu akhirat" dan "ilmu dunia". Ada juga yang menyebutnya dengan ilmu syar'iyyah dan ilmu ghairu syariyyah. Bahkan ada juga sebutan lainnya seperti al-ulum al-diniyyah dan al-'ulum al-'aqliyyah (Muryi, 1986:193). Maka pada dasarnya istilah dikotomi pendidikan terfokus hanya pada dua bagian besar yakni ilmu-ilmu tanziliyah yaitu ilmu-ilmu yang dikembangkan akal manusia terkait dengan nilai-nilai yang diturunkan Allah baik dalam kitabnya maupun hadits-hadits Nabi Muhammad, dan ilmu-ilmu kanniyyah yaitu ilmu-ilmu yang dikembangkan akal manusia karena intraksinya dengan alam. Dalam istilah bahasa Inggris maka perbedaan kata yang dipakai dikenal dengan Islamic Knowledge dan Non Islamic Knowledge. Pada akhirnya istilah dikotomi ternyata memberikan pengaruh yang cukup besar, bukan hanya untuk pendidikan Islam saja, akan tetapi juga pada agama-agama non Islam, sebut saja agama besar lainnya yakni Nasrani dan Yahudi.

Istilah lain dari dikotomi ilmu yang lebih menukik pada akar ilmu adalah pandangan dari A. Malik Fadjar yang mengistilahkan dikotomi dengan bellenis untuk ilmu umum atau ilmu modern dan semitis untuk ilmu agama. Gagasan bellenis berasal dari Yunani klasik yang ciri menonjolnya memberikan porsi yang amat besar kepada 
otoritas akal, mengutamakan sikap rasional serta lebih menyukai ilmu-ilmu sekuler. Sedangkan gagasan semitis mewarnai alam pikiran kaum agamawan, terutama agama Yahudi dan Nasrani yang mendahului Islam, dengan ciri memberikan porsi yang amat besar kepada otoritas wahyu, sikap patuh terhadap dogma serta berorientasi kepada ilmu-ilmu keagamaan (Fadjar, 1999:99-100). Dengan begitu, pada zaman Yunani justru dikotomi ilmu melebar sangat jauh melebihi ketika saat sekarang ini.

Istilah lain yang diungkap oleh Harun Nasution dalam buku Islam Rasional, bahwa ia menyebut sikap yang memisahkan terhadap ilmu dengan istilah dualisme ilmu (Nasution, 1995:5). Dalam dualisme, unsur-unsur yang paling mendasar dari setiap realitas cenderung dipertentangkan namun tidak saling menafikan antara keduanya, misalnya dalam ilmu teologi sebagaimana bidang keilmuan Harun Nasution mencontohkan kejahatan dan kebaikan, Tuhan dan alam semesta, ruhani dan jasmani, jiwa dan badan, dan lainnya.

Dari banyaknya istilah yang dipakai dalam dikotomi pendidikan Islam maka secara garis besar semua istilah yang dipakai mengerucut pada perbedaan antara ilmu agama dan ilmu umum, yang artinya semua eksistensi ilmu dipertentangkan dan dipisahkan antara satu dengan lainnya dalam bingkai realitas yang terfregmentasi menjadi sub sistem yang masing-masing berdiri sendiri. Konsekuensi dikotomi sebagaiamana yang disebutkan seperti istilah di atas akan berimplikasi pada keterasingan ilmu-ilmu agama terhadap kemodernan dan menjauhnya kemajuan ilmu pengetahuan dari nilai-nilai agama. Jika istilah dikotomi ilmu itu hanya sekedar membedakan dengan tujuan pengklasifikasian ilmu menjadi "ilmu agama" dan ilmu "non agama", maka dikotomi menjadi hal yang biasa saja (bisa bernilai positif). Akan tetapi, jika dikotomi ilmu pengetahuan dengan mendeskriminasi salah satu ilmu pengetahuan, maka ini akan berdampak buruk bagi masingmasing ilmu pengetahuan. 


\section{Dikotomi Ilmu Dalam Sejarah Pendidikan Islam}

Terjadinya pemisahan ilmu agama dan ilmu umum terjadi pada abad pertengahan, yakni pada saat umat Islam kurang memperdulikan (baca: meninggalkan) IPTEK. Pada masa itu yang berpengaruh adalah ulama fiqih. Salah satu contohnya adalah abad pertengahan tepatnya pada abad ke-11 M. Di Madrasah Nizamiyyah terjadi penspesifikasian kurikulum yang hanya menekankan pada fiqih oriented. Sehingga semua keilmuan yang dipelajari hanya bertujuan dalam rangka untuk menopang superioritas dan penjabaran hukum Islam (Mulkan, 2010:110). Fiqh oriented education adalah ciri yang menonjol pada masa itu sehingga madrasah Nizhamiyah benar-benar menjadi model pendidikan yang dikotomi (Mas'ud, 2002:110). Selain dari ulama fiqih, ada juga perkembangan yang sangat pesat dalam Islam yakni Tarekat. Kedua bidang ini menanamkan paham taklid dan membatasi kajian agama pada ilmu tafsir, tauhid, dan seluruh ilmu yang sampai sekarang disebut ilmu agama, serta menimbulkan sulitnya mengubah anggapan itu.

\section{Ilmu Pengetahuan Masa Nabi Muhammad dan Khulafa' al-Rasidin}

Islam diturunkan di tengah-tengah bangsa yang disebut sebagai bangsa "jahiliyah". Hal ini disebabkan karena bangsa Arab pada saat itu memiliki budaya yang dibawah standar peradaban bangsa maju. Pada masa itu bangsa Arab tidak mengenal namanya pendidikan formal seperti menuntut ilmu dan kegiatan pendidikan lainnya, maka tidak heran jika yang mengenal dan bisa tulis menulis hanya ada pada golongan bangsawan, itupun hanya 17 orang saja dan dari suku Aus dan Khazraj hanya 11 orang.

Meskipun demikian, bukan berarti bangsa Arab tidak memiliki keahlian lain, mereka memiliki keahlian dalam beberapa bidang, diantaranya: (a) Astronomi, yang terbatas hanya sebagai penunjuk jalan ketika pergi berjualan ke negeri yang jauh dan untuk mengetahui musim; (b) Sedikit tentang sejarah ummat sekitarnya; (c) Pengobatan berdasarkan pengalaman; (d) Perdukunan dan semacamnya; (e) Bahasa dan sastra (Aibak, 2009:29). 
Setelah datangnya Islam, masyarakat Arab menjadi masyarakat yang sangat peduli terhadap pendidikan, pada saat itu, kurikulum yang digunakan Nabi adalah "kurikulum wahyu" yang dalam hal ini adalah al-Qur'an yang melegatimasi peran kurikulum wahyu Tuhan. Dalam praktiknya ada beberapa kegiatan yang dilakukan Nabi untuk menjelaskan ayat-ayat suci menjadi lebih kongkret diantaranya (Ibrahim, 2011:132):

a. Wahyu pertama "Iqra" yang berarti "bacalah" pada hakikatnya bertujuan menghapus buta aksara bangsa Arab saat itu. Dalam praktiknya nabi sering membebaskan tawanan perang bagi yang megajarkan ummat Islam baca tulis.

b. Mempertahankan kekuatan menghapal sahabat. Aplikasi nyatanya adalah sahabat diperintahkan untuk menghapal alQur'an.

c. Mengajarkan tulis menulis. Aplikasinya adalah para sahabat yang sudah dipercaya diperintahkan menulis wahyu seperti Zaid bin Tsabit, Ali bin Abi Tholib dan sahabat-sahabat yang lain.

Pada periode Nabi, pendidikan dilakukan dari berbagai macam disiplin keilmuan akan tetapi pada saat itu, fokus utama Nabi adalah ilmu yang ada dalam wahyu. Dengan bimbingan Nabi Muhammad maka berlangsunglah kegiatan-kegiatan pendidikan. Mula-mula di sebuah tempat bernama Darul Arqam di Makkah, setelah hijrahnya Nabi ke Madinah, di bangun kuttab di emperan Masjid Nabawi. Kuttab tersebut berlangsung dari generai ke generasi sehingga pada abad ke-2 $\mathrm{H}$. hampir di setiap desa di dunia Islam telah memilikinya. Budaya ilmu yang telah dirintis Nabi Muhammad secara umum tetap dilanjutkan dan dikembangkan dizaman khulafaurrasidin. Meskipun penuh kehati-hatian dan sedikit disibukkan oleh pengembangan wilayah Islam. Khalifah yang pertama yang menggantikan Nabi Muhammad dalam memimpin umat Islam adalah Abu bakar as-Siddik, yang dalam pemerintahannya diguncang berbagai pemberontakan oleh orangorang murtad, orang-orang yang mengaku sebagai nabi dan orangorang yang enggan membayar zakat. 
Pola pendidikan pada masa Abu bakar as-Siddik masih seperti pada zaman nabi Muhammad, baik dari segi materi maupun lembaga pendidikannya. Dari segi materi pendidikan Islam terdiri dari pendidikan tauhid atau keimanan, akhlak, ibadah, kesehatan dan lain sebagainya.

Pola pendidikan pada masa Umar bin Khattab dilihat dari perspektif kurikulum, pada masa Khalifah Umar bin Khattab mata pelajaran yang diberikan adalah membaca dan menulis al-Qur'an dan menghafalnya serta belajar pokok-pokok agama Islam. Pendidikan masa Umar bin Khattab ini lebih maju dibandingkan dengan masa sebelumnya. Pada masa ini tuntutan untuk belajar Bahasa Arab juga sudah mulai tampak, orang yang baru masuk Islam dari daerah yang ditaklukkan harus belajar Bahasa Arab, jika ingin belajar dan memahami pengetahuan Islam. Oleh karena itu, pada masa Khalifah Umar bin Khattab sudah terdapat pengajaran Bahasa Arab. Kemajuan pada masa Umar disebabkan karena kondisi Negara dalam keadaan aman. Pada masa itu umar menetapkan masjid sebagai pusat pendidikan, selain itu telah terbentuknya pusat-pusat pendidikan di berbagai kota dengan pengembangan materi seperti ilmu bahasa, menulis, dan pokokpokok ilmunya. Pendidikan diatur dibawah gubernur serta didukung oleh kemajuan-kemajuan lain seperti jawatan pos, kepolisian, baitul mal, dan sebagainya.

Dan pada masa Khalifah Utsman bin Affan, pelaksanaan pendidikan Islam tidak jauh berbeda dengan masa sebelumnya. Pendidikan pada masa ini hanya melanjutkan apa yang telah ada, hanya sedikit terjadi perubahan yang mewarnai pendidikan Islam. Para sahabat yang berpengaruh dan dekat dengan Nabi Muhammad yang diperbolehkan meninggalkan Madinah dimasa Umar bin Khattab, diberikan kelonggaran untuk keluar dan menetap di daerah-daerah yang mereka sukai. Pada masa Utsman Bin Affan yang berpengaruh luar biasa bagi perkembangan pendidikan Islam selanjutnya, yaitu pengkodifikasian tulisan ayat-ayat al-Qur'an yang berserakan. 
Pada kepemimpinan Ali bin Abi Thalib umat Islam diguncang oleh peperangan saudara yaitu peperangan antara Ali dan Aisyah beserta Thalhah dan Abdullah bin Zubair (perang Jamal) dan perang melawan Muawiyah (Perang Siffin). Keadaan ini membuat pemerintahan Ali tidak kondusif terhadap keberlangsungan pendidikan terlebih dalam pengembangan ilmu pengetahuan. Dengan kerincuan politik pada masa Ali berkuasa, kegiatan pendidikan mendapat hambatan yang sangat tinggi (Ibrahim, 2011:133). Konsekuensi logisnya adalah tidak difokuskannya pemerintahan pada bidang pendidikan.

Berdasarkan diskripsi tersebut, dapat disimpulkan pola pendidikan pada masa Nabi Muhammad dan khulafaurrasidin tidak terlalu jauh berbeda, penekanan terhadap semua ilmu disamaratakan, akan tetapi memang pada saat itu, ilmu agama mendominasi dikarenakan tidak terlalu banyaknya ilmu pengetahuan umum yang mempunyai tokoh dan saat itu sumber pengetahuan yang ada hanya mengandalkan al-Qur'an dan alHadits.

\section{Ilmu Pengetabuan Masa Bani Ummayyah}

Pada masa Bani Umayyah semua aspek kebudayaan dimajukan, salah satunya adalah mengembangkan ilmu pengetahuan. Kalau pada masa Nabi dan Khulafaurrasidin fokus utamanya adalah ilmu al-Qur'an dan al-Hadits maka pada masa Bani Ummayah sesuai kebutuhan zaman dan kebutuhan kerajaan maka dikembangkan ilmu-ilmu yang ada sebelum Islam. Ilmuan-ilmuan Yahudi, Nasrani, dan agama Zoroaster yang setelah masuk Islam masih tetap memelihara ilmu-ilmu Yunani dan mereka mendapatkan perlindungan. Bahkan diantara mereka ada yang mendapatkan jabatan tinggi di istana khalifah. Ada yang menjadi dokter pribadi, bendaharawan atau wazir. Sehingga kehadiran mereka menjadikan jalan masuk terhadap perkembangan keilmuan para khalifa, seperti Khalid ibnu Yazid yang merupakan cucu Muawiyyah yang tertarik kepada ilmu-ilmu kimia dan memerintahkan sarjana Yunani yang bermukim di Mesir untuk menerjemahkan buku-buku kimia dan 
kedokteran ke dalam bahasa Arab dan itu menjadi terjemahan pertama dalam sejarah (Ibrahim, 2011:134).

Al-Malik memberikan perhatian pada bimaristan yaitu rumah sakit sebagai tempat berobat dan perawatan orang-orang sakit, serta sebagai tempat studi kedokteran. Konsep rumah sakit ini menjadikan perbedaan rumah sakit Islam dan sebelum Islam. Dalam tradisi keilmuan bani Muawwiyah terdapat 4 pembidangan jenis keilmuan, yakni:

1. Ilmu pengetahuan bidang agama, semua yang bersumber dari al-Qur'an dan al-Hadits.

2. Ilmu pengetahuan bidang sejarah, segala ilmu yang membahas tentang perjalanan hidup, kisah dan riwayat.

3. Ilmu pengetahuan bidang bahasa, nahwu, sharaf dan lain-lain.

4. Ilmu pengetahuan bidang filsafat, segala ilmu yang pada umumnya berasal dari bangsa asing, seperti mantiq, kedokteran, kimia, astronomi, ilmu hitung dan lain-lain.

Keempat bidang ilmu dikaji dan dipergunakan saling bahumembahu. Satu bidang ilmu membutuhkan bidang ilmu lainnya. Ahli ilmu agama akan memerlukan ilmu filsafat dan sejarah dan begitu juga sebaliknya. Pada masa Bani Ummayyah ini, hampir bisa dipastikan tidak adanya dikotomi ilmu pengetahuan yang mencolok, kalaupun ada pengklasifikasian ilmu agama dan ilmu umum akan tetapi pengklasifikasian tersebut tidak mendeskriditkan salah satu dari keilmuan yang ada. Hubungan yang baik terjalin antara semua ilmu pengetahuan dan pihak kerajaan mendukung penuh semua kegiatan keilmuan.

\section{Ilmu Pengetabuan Masa Daulah Abbasiyah}

Masa Abbasiyah menjadi masa keemasan bagi peradaban Islam, hal ini sangat memungkinkan karena bahasa arab telah mencapai taraf kesempurnaan sehingga berbagai buku dari berbagai disiplin keilmuan bangsa yang mempunyai peradaban tinggi seperti Yunani dan Romawi bisa di terjemahkan ke dalam bahasa Arab. Kondisi ini juga didukung oleh prioritas dari para khalifah yang lebih fokus 
El-HiKMAH, Volume 8, Nomor 2, Desember 2014

pada pembinaan dan peradaban Islam dibandingkan dengan perluasan wilayah.

Dalam masa Daulah Abbasiyah, ada sepuluh khalifah yang merupakan masa kejayaan (keemasan) peradaban Islam, dimana Bagdad mengalami kemajuan ilmu pengetahuan yang pesat. Disisi lain, kemakmuran masyarakat mencapai tingkat tertinggi. Periode ini juga berhasil menyiapkan landasan bagi perkembangan filsafat dan ilmu pengetahuan dalam Islam. Namun setelah periode ini berakhir, pemerintahan Bani Abbas mulai menurun dalam bidang politik, meskipun filsafat dan ilmu pengetahuan terus berkembang.

Gerakan membangun ilmu pengetahuan secara besar-besaran dirintis oleh Khalifah Ja'far al-Mansur dan puncak kemajuannya pada masa Khalifah Harun Ar-Rasyid. Pada masa ini dilakukan sebuah gerakan penerjemahan berbagai buku Yunani dengan menggaji para penerjemah dari golongan Kristen dan penganut agama lainnya yang ahli. Ia juga mendirikan sekolah yang salah satunya adalah Baitul Hikmah, sebagai pusat penerjemahan yang berfungsi sebagai perguruan tinggi dengan perpustakaan yang besar. Perpustakaan pada masa itu lebih mirip dengan universitas pada zaman sekarang karena perpustakaan saat itu bukan hanya terdapat kitab saja, akan tetapi saat itu perpustakaan dijadikan tempat bertemunya para ahli ilmu untuk berdiskusi, berdebat dan beradu argumen.

Pencapaian kemajuan dunia Islam pada bidang ilmu pengetahuan pada masa Abbasiyah berkembang secara cepat dan beragam. Tidak ada perbedaan ilmu yang mencolok antara ilmu agama dan ilmu umum (kalaupun ada perbedaan maka perbedaan itu sebagai upaya para ahli ilmu zaman itu untuk mengklasifikasikan ilmu saja dan tanpa menganggap rendah ilmu lain dan menganggap tinggi ilmu masing-masing). Hal ini terlihat dengan banyaknya budaya dari Negara-negara luar Arab yang masuk, seperti budaya Yunani, Persia, India dan yang lainnya. Darri kajian keilmuan yang dilakukan maka terlahirlah banyak bidang ilmu diantaranya bidang astronomi, kedokteran, filsafat, kimia, farmasi, biologi, fisika dan sejarah. Semua kemajuan ilmu pengetahuan ini karena didorong 
oleh motif sosial sehingga yang ikut serta mensukseskan gerakan ini tidak hanya dari kalangan penguasa, akan tetapi juga dilakukan oleh masyarakat, pengusaha, dan cendikiawan.

Zaman Abbasiyah selain melahirkan bidang-bidang ilmu baru, zaman Abbasiyah juga melahirkan tokoh-tokoh besar yang tidak hanya pada tokoh agamawan akan tetapi pada bidang keiilmuan lain mempunyai tokoh besar juga. Diantara tokoh-tokoh besar pada zaman Abbasiyah adalah Al-ghazali, Ibnu Sina, Al-Farabi, Ibnu Rusyd, al- Biruni, Jabir Bin Hayyan, al-Khawarizmi, al-Kindi, alFarazi, al-Fargani, al-Bitruji, Abu Ali al-Hasan bin Haythami, Ibnu Khaldun, ar-Razi, al-Idrisy dan banyak lagi ilmuan lain. Dari banyaknya ilmuan pada saat itu, para ilmuan tidak hanya menguasai satu bidang keilmuan saja, akan tetapi banyak ilmuan yang menguasai disiplin ilmu yang berbeda dari keilmuan dasarnya.

Pada masa awal Abbasiyah (masa kejayaan Islam) ilmu pengetahuan dikembangkan dengan sangat pesat, semua jenis keilmuan mengalami kemajuan akan tetapi pada masa pertengahan dan masa akhir Abbasiyah ilmu pengetahuan sudah dirasuki dikotomi ilmu pengetahuan sehingga membuat keilmuan mengalami pengkotak-kotakan. Al-hasil dikotomi ilmu pengetahuan terjadi seiring kemunduran peradaban Islam. Pengetahuan mengalami pendikotomian dan peradaban mengalami kemunduran.

\section{Al-Ghazali dan Tuduhan Pendikotomian Ilmu}

Dalam sejarah pendidikan Islam, ada beberapa tokoh yang mengungkapkan tentang dikotomi ilmu, yang meskipun sebenarnya tokoh-tokoh yang bersangkutan tidak nyata-nyata membedakan secara diametral dan konfrontatif antara ilmu-ilmu yang dimaksud. Namun, pandangan tokoh tersebut berimflikasi pada generasi berikutnya dan pengklaiman secara sepihak dilakukan generasi sesudahnya. Bahkan beberapa tokoh hanya menyikapi tentang prioritas ilmu-ilmu yang harus dipelajari, baik sebagai sebuah gagasan dan ide dasar yang mereka ungkapkan sebagai langkah terobosan dalam dunia pendidikan ataupun karena mengkritisi keadaan politik yang terjadi saat itu, untuk mengkritisi penguasa 
El-HiKMAH, Volume 8, Nomor 2, Desember 2014

saat itu maka wacana yang mungkin dapat dimunculkan adalah pengutamaan ilmu tertentu untuk menyadarkan penguasa. Akan tetapi, sejarah telah mencatat (baca: kecelakaan sejarah) dan tidak bisa diubah karena sebagian umat Islam telah menganggap itu "Fatwa" baku yang "sangat benar" dan "wajib diikuti" tanpa menelaah maksud hakikinya.

Di antara tokoh-tokoh yang mengemukakan hal-hal seputar dioktomi ilmu adalah al-Syafi'i, Ibnu Taimiyah, dan al-Ghazali. Pada makalah ini, pemakalah hanya membahas al-Ghazali saja.

Sosok al-Ghazali telah banyak dijelaskan telah mampu membagi ilmu secara diametral dan terfregmentatif. Al-Ghazali tidak hanya dikenal sebagai seorang teolog dan mistikus, tetapi dia juga menguasai bidang yurisprudensi (hukum), etika, logika hingga filsafat.

Pertentangan yang sangat fenomenal terjadi antara al-Ghazali dengan Ibnu Rusyd. Perdebatan kedua tokoh ini justru menjebak keduanya pada sikap yang berlebihan, Al-Ghazali mewakili daerah Timur terjebak pada dunia mega tasawuf dan alam ruhaniyah sedangkan Ibnu Rusyd terjebak dengan semakin tajamnya mengkritisi al-Ghazali dan meninggalkan pemikirannya serta aspek materialisme sangat ditonjolkan (Arifin, 1997:65). Al-Ghazali mendapatkan kesuksesan yang besar di daerah Timur berkat pemikiran dogmatis-normatif-sufistik, sementara Ibnu Rusyd mendapatkan kesuksesannya di dunia Barat, karena pola pikirnya yang rasional-empiris.

Al-Ghazali memperinci ilmu secara detail dan berusaha membangun pengklasifikasian ilmu antara lain :

1. Ilmu yang dihadirkan dan ilmu yang dicapa.

2. Ilmu-ilmu teoritis dan praktis

3. Ilmu-ilmu keagamaan dan ilmu intelektual

4. Ilmu fardu ain dan fadu kifayah

Fakta pengklasifikasian ini akhirnya membentuk paradigm keilmuan dikotomi pasca pengklasifikasian ilmu dari al-Ghazali tersebut. Akhirnya dikotomi ilmu agama dan sekuler sudah menghancurkan esensi dan eksistensi ilmu sehingga berakibat pada 
dehumanisasi, pengerusakan alam, dan tindakan eksploitatif lainnya. Ilmu pengetahuan sekuler yang dikonstruksi guna memenuhi kebutuhan materi belaka dan hampa esensi. Demikian juga ilmu pengetahuan agama yang tak lepas dari problem yang cendrung sangat statis. Hal ini terjadi karena ilmu pengetahuan agama dibangun hanya untuk mengurusi problem transenden dan ritul dan tidak dibanguan atas dasar sosial sehingga mereduksi nalar berfikir kritis dan kreatifitas manusia.

Bahkan upaya untuk integrasi dari kedua ilmu pengetahuan ini (ilmu agama dan ilmu umum ) tersebut masih menambah persoalan pada lembaga pendidikan Islam yang semakin ruwet. Karena hingga saat ini, belum tersusunnya sebuah konsep ilmu integral ilmu yang mampu mengatasi dikotomi ilmu umum dan ilmu agama itu sendiri. Jika integrasi ilmu ini dipaksakan bisa saja mengakibatkan ambivalensi terhadap peserta didik yang secara langsung atau tidak langsung berpengaruh terhadap perkembangan jiwanya.

\section{Catatan Akhir}

Berbagai penjelasan yang bersifat ekplanatif tersebut dan juga dari hasil pelacakan serta interpletasi atas kronologi sejarah yang mengiringi sikap paradigmatik dikotomik umat Islam terhadap ilmu seperti yang sudah dikemukakan dapat disimpulkan bahwa dalam perspektif Islam, sikap atau paham dikotomis berlebihan yang membedakan, memisahkan (kristalisasi) dan mempertentangkan antara ilmu-ilmu agama dan ilmu-ilmu non agama (ilmu umum) atau sebutan lainnya bukan hanya tidak diperbolehkan, bahkan bertentangan dengan semangat Islam sebagaia agama dan petunjuk hidup manusia untuk kebahagiaan dunia sampai kelak di akhirat.

Islam justru sebaliknya, sangat menganjurkan eksplorasi ilmu pengetahuan dengan tidak memisahkan dan mempertentangkan antara ilmu agama dan ilmu non agama. Dalam Islam, sebenarnya tidak ada pendikotomian ilmu, yang ada hanyalah pengklasifikasian ilmu, akan tetapi pada tataran praktiknya pengklasifikasian ilmu tersebut salah diartiakn oleh banyak kalangan masyarakat muslim itu sendiri. 
El-HiKMAH, Volume 8, Nomor 2, Desember 2014

Banyaknya paham dalam tradisi keislaman membuat saling klaim kebenaran dan keadaan ini memperparah jarak antara ilmu agama dan ilmu non agama serta kegembiraan berlebihan terhadap ilmu filsafat sehingga terlalu dibukanya ilmu pengetahuan Islam dan kekuranghati-hatian ilmuan muslim dalam memadukan filsafat dengan Islam.

\section{Daftar Pustaka}

A. Malik Fadjar, Reorientasi Pendidikan Islam. Jakarta: Yayasan Pendidikan Islam Fajar Dunia, 1999.

Abdul Munir Mulkan, Membangun Tradisi Ilmu Pesantren, dalam Umiarso dan Nur Zazin, Pesantren di Tengah Arus Mutu Pendidikan: Menjawab Problematika Kontemporer Manajemen Mutu Pesantren. Semarang : RASaiL, 2010.

Abdurrahman Mas'ud, Menggagas Format Pendidikan Nondikotomik: Humanisme Religius Sebagai Paradigma Pendidikan Islam. Yogyakarta: Gama Media, 2002.

Ahmad Munir Muryi, al-Tarbiyah al-islamiyab: Ushuluba Wa Tathawwuruba. Kairo: Maktabah Dar al-'Alam, 1986.

Dedi Supriyadi, Sejarah Peradaban Islam. Bandung: Pustaka Setia, 2008.

Hadi Masruri dan Imron Rossidy, Filsafat Sains Dalam Al-Qur'an. Malang: UIN Malang Press, 2007.

Harun Nasution, Islam Rasional: Gagasan dan Pemikiran Prof. Dr. Harun Nasution, Syaiful Muzani (ed.). Bandung: Mizan, 1995.

Hasan Ibrahim, Tarikh al-Islam, dalam Dikotomi Pendidikan Islam. Bandung: PT. Rosdakarya, 2011.

Kutbuddin Aibak, Teologi Pembacaan : Dari Tradisi Pembacaan Paganis Menuju Rabbani, Yogyakarta: Teras, 2009.

Moh. Shofan, Islamisasi Ilmu Pengetahuan, dalam Logos, Jurnal Ilmuilmu Sosial dan humaniora, Vol. 4, No. 1 Januari 2005, 6.

Moh. Sofan, Pendidikan Berparadigma Profetik: Upaya Konstruktif Membongkar Dikotomi Sistem Pendidikan Islam. Yogyakarta: IRCISoD dan UGM Press Jawa Timur, 2014. 
Mujammil Qomar, Epistemologi Pendidikan Islam: Dari Metode Rasional Hingga Metode Kritik. Jakarta: Erlangga, 2006.

Mulyadi Kertanegara, Integrasi Ilmu: Sebuah Rekonstruksi Holistik. Bandung: Arasy Mizan, 2005.

Pius A. partanto dan M. Dahlan al-barry, Kamus Ilmiah Populer (Surabaya: Arkola, 1994.

Syamsul Arifin, Kritik Ismail Raji al-Faruqi Terbadap Fenomena Dikotomi Pendidikan Islam, Tesis. Yogyakarta: Universitas Islam Negeri Sunan Kalijaga, 1997.

Tim Penyusun Kamus Pusat Bahasa, Kamus Besar Bahasa Indonesia. Jakarta: Balai Pustaka, 2001.

Yuldelasharmi, Dikotomi Ilmu Pengetahuan: Akar Timbulnya Dikotomi Imu Dalam Peradaban Islam, dalam Samsul Nizar (ed.), Sejarah Pendidikan Islam: Menelusuri Jejak Sejarah Pendidikan Era Nabi Mubammad Sampai Indonesia. Jakarta: Kencana, 2009. 